\title{
Persepsi terhadap Beban Kerja dengan Turnover Intention pada Karyawan
}

\author{
Adam Tirtaputra, Lie Tjoen Tjie, Frensen Salim
}

Fakultas Psikologi, Universitas Gunadarma email: adamtirta@yahoo.com

\begin{abstract}
Abstrak
Salah satu masalah yang timbul yang berkaitan dengan sumber daya manusia adalah turnover. Karyawan yang melakukan turnover biasanya disebabkan karena adanya beban kerja yang berlebihan. Banyaknya tuntutan-tuntutan pekerjaan yang harus dipenuhi oleh karyawan menyebabkan karyawan merasa terbebani dan menimbulkan adanya intensi untuk meninggalkan perusahaan guna mencari pekerjaan yang lebih baik daripada pekerjaan sebelumnya. Penelitian ini bertujuan untuk mengetahui hubungan antara persepsi terhadap beban kerja dengan turnover intention pada karyawan. Sampel penelitian ini adalah karyawan dengan klasifikasi jabatan sekelas staff atau di bawah supervisor perusahaan dengan penghasilan yang kurang dari Rp $5.000 .000 /$ bulan. Pengambilan sampel dengan non-probability sampling, yaitu purposive sampling. Hasil analisis korelasi Product Moment Pearson menunjukkan ada hubungan positif yang signifikan antara persepsi terhadap beban kerja dengan turnover intention pada karyawan. Dengan demikian, semakin tinggi persepsi terhadap beban kerja maka, semakin tinggi pula turnover intention karyawan. Dan juga sebaliknya, semakin rendah persepsi terhadap beban kerja maka, semakin rendah pula turnover intention karyawan.
\end{abstract}

Kata kunci: persepsi terhadap beban kerja, turnover intention, karyawan

\section{Perception of Workload with Turnover Intention on Employees}

\begin{abstract}
One of the issues that arise on human resources is turnover. Employees who do turnover are usually caused by excessive workload. The number of job demands causes employees to feel overwhelmed and cause the intention to leave the company to find a better job than previous jobs. This study aims to determine the relationship between perceptions of workload with employee turnover intention. Samples were employees with classification class office staff or under the supervisor of companies with revenue of less than Rp 5.000.000/month. Sampling with non-probability sampling, are purposive sampling. Based on the result of Pearson Product Moment correlation analysis shows that there is a significant positive relationship between perceptions of workload with employee turnover intention. Thus, the higher perception of the workload then, also higher the employee's turnover intention. And vice versa, the lower perception of the workload, also lower the employee's turnover intention.
\end{abstract}

Keywords: perception of workload, turnover intention, employees

\section{Pendahuluan}

Setiap perusahaan sangat mengandalkan dan sangat membutuhkan sumber daya manusia yang ideal guna membangun perusahaannya agar dapat terus berkembang menjadi perusahaan yang lebih baik dan menonjol dibandingkan perusahaan lain yang bergerak pada bidang yang sama. Dengan adanya SDM yang memadai membuat perusahaan tersebut mampu bersaing dengan perusahaan lain yang bergerak pada bidang yang sama. Oleh karena itu, setiap perusahaan selalu menyeleksi dengan ketat untuk setiap sumber daya manusia yang ingin masuk ke dalam perusahaan itu. Seleksi yang ketat membuat setiap sumber daya manusia ingin meningkatkan kemampuan dirinya dan mencari perusahaan yang lebih baik daripada yang sebelumnya (Dewi, 2013).

Arthur (1994) menyatakan bahwa perspektif tentang sumber daya manusia (SDM) strategis paling mendasar adalah asumsi keberhasilan sebuah kinerja perusahaan dipengaruhi oleh tindakan dan peran sumber daya manusia (SDM) yang dimiliki oleh perusahaan misalnya bagaimana suatu organisasi dapat mengelola dan mendidik karyawan- 
nya sehingga memiliki kenyamanan terhadap pekerjaan tempat seseorang tersebut bekerja, dengan memberikan timbal balik yang selaras antara penerimaan dan pengorbanan karyawan pada institusinya.

Tetapi karena banyaknya tuntutantuntutan dalam pekerjaan yang harus dipenuhi menyebabkan setiap karyawan merasa terbebani yang membuat adanya intensi untuk meninggalkan perusahaan guna mencari pekerjaan yang lebih baik daripada sebelumnya menurut pekerja yang ingin meninggalkan perusahaan tersebut. Setiap perusahaan pastinya akan membuat pekerjaan tersebut menjadi tidak membebankan karyawannya, apabila terjadi banyak turnover terhadap perusahaan, maka perusahaan tersebut pastinya akan sulit untuk berkembang untuk bersaing dengan perusahaan yang lain (Du Plooy \& Roodt, 2013). Salah satu masalah yang timbul yang berkaitan dengan sumber daya manusia adalah turnover. Karyawan yang melakukan turnover biasanya disebabkan karena adanya beban kerja yang berlebihan sehingga menyebabkan karyawan mencari perusahaan yang lebih baik dibandingkan perusahaan sebelumnya. Lalu dengan adanya persepsi terhadap beban kerja juga membuat karyawan meningkatkan kemampuannya karena sadar dengan persaingan yang ada di lapangan pekerjaan saat ini (Du Plooy \& Roodt, 2013).

Menurut Xiaoming, Ma, Chang, dan Shieh (2014), turnover berkenaan dengan lingkungan industri dan organisasi yaitu meninggalkan pekerjaan baik secara sukarela atau tanpa sadar (dikeluarkan). Turnover yang sering digunakan untuk mengukur masa kerja (berapa lama pekerja tetap pada pekerjaan) serta kepuasan atau ketidakpuasan kerja.

Du Plooy dan Roodt (2013) menyatakan seperti hasil yang dikemukakan oleh APA's Work Stress Survey, bahwa persentase karyawan di US yang mengalami turnover pada tahun 2012 sebesar $36 \%$ dan karyawan yang mempunyai keinginan untuk bekerja di tempat lain sebesar $28 \%$. Banyak hal yang menyebabkan seseorang mempunyai turnover intention.

Turnover terjadi di berbagai organisasi dikarenakan keinginan seseorang untuk mencari kenyamanan pada pekerjaannya. Perusahaan-perusahaan di Indonesia menghadapi masalah dalam mempertahankan karyawan yang berprestasi tinggi (top performing employees). Bahkan, masalah tersebut lebih tinggi dibanding kebanyakan negara-negara Asia Pasifik. Masalah lain yang dihadapi perusahaan-perusahaan di Indonesia adalah mempertahankan karyawan dengan keahlian khusus (critical skilled employees) dan karyawan berpotensi tinggi (high potential employee). Berdasarkan hasil survei Global Strategic Rewards (dalam Lathifah, 2008) yang dilakukan oleh Watson Wyatt, kehilangan karyawan berprestasi tinggi dan karyawan dengan keahlian khusus sudah menjadi masalah yang perlu diwaspadai oleh industri di Indonesia. Contohnya sektor migas, sudah terjadi indikasi aliran positif dari Indonesia ke luar negeri, seperti ke Arab Saudi, Malaysia, bahkan Eropa, karena tawaran paket renumerasi yang jauh lebih menarik. Sementara di Indonesia, paket remunerasinya masih dikaitkan dengan keadaan rata-rata domestik. Contoh lain yaitu di sektor perbankan, khususnya untuk tenaga dengan keahlian khusus. Hasil survei yang dilakukan sejak pertengahan tahun 2006-2007 itu menunjukkan turnover untuk posisi-posisi penting (level manajerial dan di atasnya) di industri perbankan antara 6,3\%-7,5\%. Sedangkan turnover karyawan di industri pada umumnya hanya berkisar 0,1 $0,74 \%$.

Kasus di Indonesia, fenomena turnover intention disadari benar oleh akademisi maupun praktisi. Setiap tahunnya ada sekitar $10-12 \%$ karyawan yang melakukan turnover. Banyaknya perusahaan-perusahaan baru yang didirikan, turut memberikan angin segar kepada para karyawan untuk mencoba sebuah peruntungan baru. Berkembangnya jumlah usaha-usaha waralaba dan bisnis online, turut mendorong tingginya intensitas turnover di sebuah perusahaan. Selain itu, tak dapat dipungkiri adanya sistem kontrak membuat karyawan mengantisipasi sedini mungkin sebelum perusahaan tersebut melakukan PHK kepada dirinya (Lathifah, 2008). Turnover secara tidak langsung telah membuat berkurangnya tingkat produktivitas dalam 
sebuah perusahaan. Selain itu, perusahaan juga mengalami kerugian lain karena perlu mengeluarkan biaya tambahan dalam rangka melakukan perekrutan karyawan baru. Bahkan, beberapa manajer personalia mengalami frustrasi ketika mengetahui bahwa proses rekrutmen yang telah berhasil menjaring staf yang berkualitas pada akhirnya sia-sia karena staf yang baru direkrut tersebut memilih bekerja di perusahaan lain (Lathifah, 2008).

Di Indonesia perkiraan peningkatan turnover dihasilkan dari studi oleh Hay Group bekerja sama dengan Centre for Economics and Business Research seperti dilansir TopCareer Magazine (2013). Studi tersebut memperkirakan jumlah karyawan yang akan berhenti pada tahun 2014 dapat mencapai 161,7 juta atau meningkat $12,9 \%$ bila dibandingkan dengan tahun 2012, sedangkan di tahun 2015 turnover intention pada karyawan akan semakin meningkat hingga $13,4 \%$. Kawasan Asia Pasifik diperkirakan akan mengalami lonjakan terbesar dalam tingkat pergantian karyawan tahun 2014. Tingkat turnover di Asia Pasifik akan mengalami kenaikan tertinggi di seluruh dunia, yakni naik $21,5-25,5 \%$ selama periode 2012-2018.

Menurut Abelson (1987) turnover intention adalah keinginan individu untuk meninggalkan organisasi lain guna mencari alternatif pekerjaan lain. Keletihan yang ada pada saat bekerja sering kali membuat karyawan menjadi terbebani dengan pekerjaannya, seseorang tersebut menjadi terbebani dan menafsirkan bahwa pekerjaan yang dikerjakan berat. Karena adanya perasaan terbebani akan pekerjaannya pastinya akan ada niat untuk meninggalkan perusahaan tempat seseorang tersebut bekerja. Penyebab turnover karyawan pastinya bukan hanya beban kerja terhadap perusahaan, ketidakpuasan kerja dan lingkungan kerja yang tidak mendukung juga pasti akan mempengaruhi niat untuk meninggalkan perusahaan tersebut.

Salah satu faktor yang dikemukakan oleh Allen dan Meyer (1997) yaitu faktor atribut peran dan pekerjaan meliputi tantangan pekerjaan, lingkup jabatan, pengorbanan, tingkat kesulitan dalam pekerjaan, ambiguitas peran, dan konflik peran. Hal ini merupakan beban kerja yang dirasakan, di mana membutuhkan aktivitas mental dan fisik dari karyawan. Gawron (2008) mendefinisikan beban kerja sebagai seperangkat tuntutan tugas, sebagai upaya, dan sebagai kegiatan atau prestasi. Beban dapat berupa beban fisik maupun beban mental. Beban fisik dapat dilihat dari seberapa banyak karyawan menggunakan kekuatan fisiknya, dan juga dapat berupa beban kerja mental yang dapat dilihat dari seberapa besar aktivitas mental yang dibutuhkan untuk mengingat hal-hal yang diperlukan, konsentrasi, mendeteksi permasalahan, mengatasi hal-hal yang tak terduga dan membuat keputusan dengan cepat yang berkaitan dengan pekerjaan sejauh mana tingkat keahlian dan prestasi kerja yang dimiliki individu. Sehingga dapat dikatakan bahwa suatu pekerjaan merupakan beban kerja bagi karyawannya jika memiliki beban kerja fisik maupun mental. Beban kerja yang dirasakan oleh seorang pekerja dapat menjadi faktor penekan yang menghasilkan kondisi-kondisi tertentu, sehingga menuntut manusia memberikan energi atau konsentrasi (perhatian) yang lebih harus diselesaikan dalam jangka waktu tertentu. Beban kerja yang terlalu berlebihan atau terlalu sedikit dapat menimbulkan gangguan atau penyakit akibat bekerja. Beban kerja yang berlebihan dapat menimbulkan kelelahan baik fisik maupun mental dan reaksi-reaksi emosional seperti sakit kepala, gangguan pencernaan dan mudah marah. Sedangkan beban kerja yang terlalu sedikit, di mana pekerjaan yang terjadi karena pengulangan gerak, akan menimbulkan rasa kebosanan (Gawron, 2008).

Robbins dan Judge (2007) menyatakan bahwa positif negatifnya beban kerja merupakan masalah persepsi. Persepsi didefinisikan sebagai suatu proses di mana individu mengorganisasikan dan menafsirkan kesan indera mereka agar memberi makna kepada lingkungan mereka. Persepsi terhadap beban kerja merupakan penilaian individu mengenai sejumlah tuntutan tugas atau kegiatan yang membutuhkan aktivitas mental misalnya untuk mengingat hal-hal yang diperlukan seperti konsentrasi, mendeteksi permasalahan, mengatasi kejadian yang tak terduga dan mem- 
buat keputusan dengan cepat yang berkaitan dengan pekerjaan dan kekuatan fisik seperti mengetik keyboard, mengangkut dan sebagainya yang harus diselesaikan dalam jangka waktu tertentu. Setiap pekerja dapat merasakan beban kerja yang berbeda-beda, hal ini berkaitan dengan adanya perbedaan pemahaman, penghayatan, pengalaman, serta kemampuan tiap individu terhadap pekerjaannya.

Persepsi terhadap beban kerja berkaitan dengan faktor atribut peran dan pekerjaan. Hal ini dikarenakan persepsi terhadap beban kerja merupakan hal yang erat dengan suatu pekerjaan, di mana individu memberikan penilaian mengenai sejumlah tuntutan tugas atau kegiatan yang membutuhkan aktivitas mental dan fisik yang harus diselesaikan dalam waktu tertentu, apakah memiliki dampak positif atau negatif terhadap pekerjaannya. Hal ini tentunya berkaitan dengan munculnya turnover intention individu di mana dalam pekerjaan pastinya setiap karyawan memiliki niat untuk meninggalkan perusahaan yang disesuaikan dengan kebutuhan seseorang tersebut masing-masing (Dewi, 2013).

Karena adanya beban kerja, menimbulkan suatu intensi untuk meninggalkan perusahaan, setiap orang menginginkan kenyamanan dalam pekerjaannya, apabila seseorang merasa tidak nyaman dengan suatu pekerjaannya, maka seseorang tersebut pasti akan ingin mencari pekerjaan yang lebih baik daripada sebelumnya. Menurut Xiaoming, Ma, Chang, dan Shieh (2014), beban kerja memiliki efek dengan turnover intention, dikondisikan pada karyawan medis di mana semakin besar beban kerja maka semakin besar juga turnover intention suatu karyawan tersebut. Sebaliknya, semakin kecil beban kerja maka semakin kecil juga turnover intention pada suatu karyawan. Hal ini dapat menjadi pendapat mengenai persepsi terhadap beban kerja memiliki hubungan atau tidaknya terhadap turnover intention, di mana semakin tinggi persepsi terhadap beban kerja maka semakin tinggi juga intensi untuk meninggalkan suatu perusahaan dan mencari perusahaan tempat seseorang bekerja yang lebih baik dibandingkan dengan yang sebelumnya. Setiap perusahaan membutuhkan karyawan sebagai tenaga kerja yang menjalankan setiap aktivitas yang ada dalam organisasi perusahaan. Karyawan merupakan aset terpenting yang memiliki pengaruh yang sangat besar terhadap kesuksesan sebuah perusahaan. Tanpa mesin canggih perusahaan dapat terus beroperasi secara manual, akan tetapi tanpa karyawan, perusahaan tidak akan dapat berjalan sama sekali (Xiaoming, Ma, Chang, \& Shieh, 2014).

Berdasarkan permasalahan turnover dan adanya pendapat mengenai persepsi terhadap beban kerja yang banyak terjadi di beberapa negara dan penelitian terdahulu tentang turnover intention, peneliti merumuskan hipotesis: ada hubungan positif antara persepsi terhadap beban kerja dengan turnover intention pada karyawan. Semakin tinggi persepsi terhadap beban kerja maka semakin tinggi pula turnover intention karyawan.

\section{Metode}

\section{Partisipan}

Populasi dalam penelitian ini adalah karyawan dari 3 perusahaan di DKI Jakarta. Sampel yang digunakan dalam penelitian ini sebanyak 71 orang responden. Responden diperoleh dengan teknik non-probability sampling yaitu seleksi khusus atau purposive sampling karena terdapat kriteria-kriteria yang dibutuhkan agar sesuai dengan variabel penelitian. Karakteristik sampel dalam penelitian ini adalah karyawan laki-laki dan perempuan yang bekerja di suatu perusahaan dengan klasifikasi staff yang bukan merupakan pimpinan dari suatu perusahaan atau pada kelasnya serta yang berpenghasilan kurang dari Rp5.000.000/bulan. Pada kriteria ini, gejala-gejala perilaku individu baru dapat terlihat karena akibat dari pekerjaannya.

Adapun deskriptif responden berdasarkan data demografi dapat dilihat pada tabel 1. 
Tabel 1. Deskriptif Responden Berdasarkan Data Demografi

\begin{tabular}{llll}
\hline Data Demografi & Kategori & Jumlah (n) & Persentase (\%) \\
\hline \multirow{2}{*}{ Jenis Kelamin } & Pria & 29 & $41 \%$ \\
\multirow{3}{*}{ Usia } & Wanita & 42 & $59 \%$ \\
& $20-25$ tahun & 60 & $84 \%$ \\
\multirow{4}{*}{ Lama Bekerja } & $26-30$ tahun & 9 & $13 \%$ \\
& $31-35$ tahun & 2 & $3 \%$ \\
& $<1$ tahun & 22 & $31 \%$ \\
& $1-4$ tahun & 37 & $52 \%$ \\
\hline
\end{tabular}

Berdasarkan tabel 1, dari jumlah responden tersebut, 29 orang diantaranya adalah pria (41\%) dan 42 orang lainnya adalah wanita $(59 \%)$. Usia responden terentang antara 20 hingga 35 tahun, yang terbagi ke dalam tiga kelompok, yaitu 20-25 tahun (n $=60 ; 84 \%), 26-30$ tahun $(\mathrm{n}=9 ; 13 \%)$, dan 31-35 tahun $(n=2 ; 3 \%)$. Berdasarkan lama bekerjanya, terentang mulai dari 4 bulan hingga 7 tahun, yang terbagi menjadi tiga kelompok, yaitu kurang dari 1 tahun $(n=22$; $31 \%), 1-4$ tahun $(n=37 ; 52 \%)$, dan lebih dari 4 tahun $(\mathrm{n}=12 ; 17 \%)$. Pengisian dan pengumpulan kuesioner bersifat sukarela yang disebar secara langsung kepada responden dan melalui link/tautan dengan media google form.

\section{Pengukuran}

Metode pengumpulan data yang dipergunakan dalam penelitian ini adalah metode skala yang disebarkan kemudian dikumpulkan dan diolah dimana skala ini terdiri dari skala persepsi terhadap beban kerja dan skala turnover intention.

Skala turnover intention disusun berdasarkan dimensi-dimensi turnover intention yang dikemukakan oleh Lum, Kervin, Clark, Reid dan Sirola (1998). Aitem yang digunakan berjumlah 24 aitem setelah dilakukan modifikasi untuk kecocokkan responden terhadap skala tersebut. Skala turnover intention ini berbentuk skala Likert. Aitem-aitemnya menggunakan kategori respon-respon frekuensi perilaku partisipan dan tiap-tiap pernyataan yang ada serta mempunyai variasi jawaban sebagai berikut: Sangat Sesuai (SS), Sesuai (S), Netral (N), Tidak Sesuai (TS), dan San- gat Tidak Sesuai (STS). Setelah dilakukan uji daya diskriminasi aitem, terdapat 23 aitem yang baik dan 1 aitem gugur. Korelasi skor tingkat daya diskriminasi aitem bergerak dari angka 0,297 - 0,674 dan angka koefisien reliabilitas sebesar 0,902.

Skala persepsi terhadap beban kerja disusun berdasarkan aspek-aspek yang ada berdasarkan aspek persepsi dan aspek beban kerja yang berjumlah 26 aitem. Skala persepsi terhadap beban kerja ini berbentuk skala Likert. Aitem-aitemnya menggunakan kategori respon-respon frekuensi perilaku partisipan dan tiap-tiap pernyataan yang ada serta mempunyai variasi jawaban sebagai berikut: Sangat Sesuai (SS), Sesuai (S), Netral (N), Tidak Sesuai (TS), dan Sangat Tidak Sesuai (STS). Setelah dilakukan uji daya diskriminasi aitem, terdapat 21 aitem yang baik dan 5 aitem gugur. Korelasi skor tingkat daya diskriminasi aitem bergerak dari angka 0,273 - 0,617 dan angka koefisien reliabilitas sebesar 0,883 .

\section{Analsis Data}

Metode analisis data yang digunakan adalah analisis statistik. Penelitian ini bertujuan untuk mengetahui adanya hubungan antar variabel persepsi terhadap beban kerja dengan turnover intention. Teknik analisis data yang digunakan dalam penelitian ini adalah teknik korelasi product moment Pearson yang dibantu dengan software SPSS for windows versi 22 untuk mengetahui signifikansi korelasi. 


\section{Hasil}

Sebelum melakukan uji hipotesis, peneliti melakukan uji asumsi terlebih dahulu. Uji asumsi menggunakan uji normalitas dan uji linearitas. Uji normalitas dalam penelitian ini menggunakan koefisien normalitas Shapiro-Wilk, didapatkan hasil signifikansi sebesar $0,201(p>0,05)$ untuk skala turnover intention dan $0,162(p>0,05)$ untuk skala persepsi terhadap beban kerja. Berdasarkan nilai signifikansi kedua variabel, dapat dikatakan bahwa data yang diperoleh terdistribusi secara normal.

Tabel 2. Uji Korelasi Variable Penelitian
Selanjutnya, uji linieritas dilakukan untuk mengetahui apakah hubungan persepsi terhadap beban kerja dengan turnover intention linier atau tidak. Didapatkan hasil signifikansi uji linieritas sebesar 0,004 $(p<0,05)$ yang menunjukkan bahwa hubungan persepsi terhadap beban kerja dengan turnover intention adalah linier.

Pengujian hipotesis dilakukan dengan menggunakan teknik korelasi Product Moment Pearson dengan melihat nilai signifikansi $(p) \leq 0,05$ maka hipotesis diterima.

\begin{tabular}{llll}
\hline & & Turnover Intention & $\begin{array}{l}\text { Persepsi Beban } \\
\text { Kerja }\end{array}$ \\
\hline \multirow{2}{*}{ Turnover Intention } & $\begin{array}{l}\text { Pearson Correlation } \\
\text { Sig. (1-tailed) }\end{array}$ & 1 & $.335^{* *}$ \\
\cline { 2 - 3 } Persepsi Beban Kerja Pearson Correlation & 71 & .004 \\
\cline { 2 - 4 } & Sig.(1-tailed) & $.335^{* *}$ & 1 \\
& $N$ & .004 & 1 \\
\hline
\end{tabular}

Berdasarkan tabel 2, hasil analisis terhadap korelasi $(r)$ sebesar 0,335 dengan nilai signifikansi $0,004(p<0,05)$. Nilai tersebut menunjukkan bahwa ada hubungan positif yang signifikan antara persepsi terhadap beban kerja dengan turnover intention pada karyawan. Dengan demikian, maka hipotesis yang diajukan pada penelitian ini diterima. Semakin tinggi persepsi terhadap beban kerja maka semakin tinggi pula turnover intention karyawan, sebaliknya semakin rendah persepsi terhadap beban kerja maka semakin rendah pula turnover intention karyawan.

Selain itu, nilai $\mathrm{R}$ Square $(\mathrm{r} 2)=0,112$ menunjukkan bahwa persepsi terhadap beban kerja memberikan kontribusi sumbangan relatif sebesar $11,2 \%$ terhadap turnover intention dan sisanya $88,8 \%$ merupakan faktor lain di luar penelitian ini.

Secara keseluruhan dapat diketahui bahwa turnover intention partisipan tergolong tinggi. Adapun persepsi terhadap beban kerja partisipan tergolong sedang.

Tabel 3. Rerata Empirik dan Hipotetik untuk Semua Variabel

\begin{tabular}{llllll}
\hline Variabel & $\begin{array}{l}\text { Rerata } \\
\text { Empirik }\end{array}$ & $\begin{array}{l}\text { Rerata } \\
\text { Hipotetik }\end{array}$ & $\begin{array}{l}\text { Standar } \\
\text { Deviasi } \\
\text { Empirik }\end{array}$ & $\begin{array}{l}\text { Standar } \\
\text { Deviasi } \\
\text { Hipotetik }\end{array}$ & Kategori \\
\hline $\begin{array}{lllll}\text { Turnover Intention } \\
\text { Persepsi terhadap }\end{array}$ & 84,80 & 69 & 10,86 & 15,33 & Tinggi \\
Beban Kerja & 61,60 & 63 & 10,62 & 14 & Sedang \\
\hline
\end{tabular}

Tabel 3 merupakan statistik deskriptif rerata empirik dan hipotetik skala turnover intention dan persepsi tehadap beban kerja. Tabel tersebut menunjukkan variabel turnover intention memiliki nilai rata-rata 84,80 dengan standar deviasi 10,86 dan berada pada kate- gori tinggi. Sedangkan pada variabel persepsi terhadap beban kerja memiliki nilai ratarata 61,60 dengan standar deviasi 10,62 dan berada pada kategori sedang. 


\section{Pembahasan}

Penelitian ini bertujuan untuk mengetahui ada atau tidaknya hubungan antara persepsi terhadap beban kerja dengan turnover intention karyawan. Pengujian hipotesis dari penelitian ini menunjukkan hasil bahwa terdapat hubungan positif antara persepsi terhadap beban kerja dengan turnover intention karyawan. Hal tersebut ditunjukkan dengan angka koefisien korelasi sebesar $r x y=0.335$ dengan $p=0.004$ ( $p \leq 0.05$ ). Hubungan positif yang signifikan antara persepsi terhadap beban kerja dengan turnover intention memiliki arti bahwa artinya semakin tinggi persepsi terhadap beban kerja maka semakin tinggi juga turnover intention. Begitu juga sebaliknya, semakin rendah persepsi terhadap beban kerja maka akan semakin rendah pula turnover intention-nya. Berdasarkan hasil tersebut, hipotesis yang menyatakan adanya hubungan positif antara persepsi terhadap beban kerja dengan turnover intention dapat diterima. Selain itu, nilai $R$ Square $(r 2)=0,112$ menunjukkan bahwa persepsi terhadap beban kerja memberikan kontribusi sumbangan relatif sebesar $11,2 \%$ terhadap turnover intention dan sisanya $88,8 \%$ merupakan faktor lain di luar penelitian ini.

Terujinya hipotesis dalam penelitian ini menunjukkan bahwa individu yang memiliki persepsi terhadap kerja yang tinggi baik berupa aspek kognisi dan afeksi mengenai aktivitas mental, kekuatan fisik dan waktu memegang peranan dalam munculnya turnover intention. Turnover intention merupakan faktor penting dalam suatu organisasi, karena apabila karyawan pada suatu perusahaan yang memiliki turnover intention yang tinggi tentunya akan merugikan perusahaan dari segi sumber daya manusianya, setiap perusahaan tentunya akan memerlukan dana, waktu dan hal lainnya lebih banyak dibandingkan yang turnover intention-nya lebih rendah dikarenakan setiap perusahaan akan harus mencari karyawan baru lagi yang harus bekerja di perusahaan tersebut serta pasti tentunya setiap perusahaan menginginkan sumber daya manusia yang terbaik di antara yang terbaik dalam perusahaannya. Apa- bila suatu perusahaan memiliki sumber daya manusia yang baik tentu saja visi, misi dan tujuan dari organisasi tersebut lebih mudah untuk tercapai. Dengan adanya sumber daya manusia yang memuaskan dari setiap perusahaan, akan membangkitkan persepsi terhadap beban kerja yang lebih ringan dan tidak terasa terlalu membebani dikarenakan setiap pekerjaan yang dilakukan dianggap tidak terlalu sulit dan masih dapat diserap atau dicerna dengan perusahaan yang memiliki sumber daya manusia yang lebih baik dibandingkan perusahaan yang memiliki sumber daya manusia yang tidak lebih baik.

Menurut Pradana dan Salehudin (2015), kelebihan beban kerja memiliki hubungan yang signifikan dengan turnover intention melalui kepuasan kerja dan hubungan stres kerja. Memiliki kontra bahwa kelebihan beban kerja tidak berhubungan dengan turnover intention dengan keseimbangan kehidupan kerja. Abelson (1987) turnover intention adalah keinginan individu untuk meninggalkan organisasi lain guna mencari alternatif pekerjaan lain. Keletihan yang ada pada saat bekerja sering kali membuat karyawan menjadi terbebani dengan pekerjaannya, seseorang tersebut menjadi terbebani dan menafsirkan bahwa pekerjaan yang dikerjakan berat. Karena adanya perasaan terbebani akan pekerjaannya pastinya akan ada niat untuk meninggalkan perusahaan tempat seseorang tersebut bekerja. Penyebab turnover karyawan pastinya bukan hanya beban kerja terhadap perusahaan, ketidakpuasan kerja dan lingkungan kerja yang tidak mendukung juga pasti akan mempengaruhi niat untuk meninggalkan perusahaan tersebut.

Menurut Xiaoming, Ma, Chang, dan Shieh (2014), beban kerja memiliki efek dengan turnover intention, dikondisikan pada karyawan medis dimana semakin besar beban kerja maka semakin besar juga turnover intention suatu karyawan tersebut. Sebaliknya, semakin kecil beban kerja maka semakin kecil juga turnover intention pada suatu karyawan. Hal ini dapat menjadi pendapat mengenai persepsi terhadap beban kerja memiliki hubungan atau tidaknya terhadap turnover intention, dimana semakin tinggi persepsi ter- 
hadap beban kerja maka semakin tinggi juga intensi untuk meninggalkan suatu perusahaan dan mencari perusahaan tempat seseorang bekerja yang lebih baik dibandingkan dengan yang sebelumnya.

Hal ini tentu saja akan memberikan keuntungan bagi perusahaan maupun karyawan, dengan pekerjaan yang sesuai dengan karyawan tentu saja akan mengurangi rasa turnover intention yang ada pada setiap karyawan, tetapi akan menjadi sulit apabila hanya berpatokan terhadap sumber daya manusia yang tinggi. Dengan meneliti persepsi terhadap beban kerja dengan turnover intention dimana apabila persepsi terhadap beban kerja seseorang tinggi dengan arti kata semakin terbebani maka akan menyebabkan turnover intention yang lebih tinggi dibandingkan dengan persepsi terhadap beban kerja seseorang yang rendah. Hal ini merupakan hal yang dapat dijelaskan karena setiap orang memiliki keinginan untuk mendapatkan hasil yang lebih baik dibandingkan hal sebelumnya. Keadaan manusia yang mencari sesuatu yang lebih sempurna daripada sebelumnya akan memberikan niatan untuk keluar dari perusahaannya yang sekarang dan mencari perusahaan yang lebih baik lagi daripada sebelumnya.

Menurut Mobley, Horner, dan Hollingsworth (1978) turnover intention mengacu kepada perkiraan peluang individu bahwa individu akan keluar dari organisasi berdasarkan beberapa poin di masa depan. Beberapa poin yang dimaksudkan adalah poin-poin yang diinginkan setiap manusia atau setiap sumber daya manusia untuk menjadi lebih baik lagi dibandingkan yang sebelumnya, hal ini dapat dikatakan pantas karena manusia mencari sesuatu yang lebih baik dan terus lebih baik lagi dibandingkan yang sebelumnya. Ketidakpuasan kerja merupakan penyebab dari karyawan untuk mulai berpikir keluar dari organisasi. Karyawan akan mengevaluasi keuntungan dari mencari pekerjaan yang baru dengan biaya keluar yang akan didapatkan. Biaya ini dapat mencakup manfaat perusahaan terkait dengan lamanya karyawan bekerja (seperti, waktu liburan dan bonus), hilangnya pensiun dan jaminan ke- sehatan serta penurunan tingkat keamanan kerja (sering didasarkan pada lamanya karyawan bekerja dalam organisasi. Atas dasar ini, individu dapat memutuskan untuk mencari alternatif pekerjaan. Karyawan tersebut mengevaluasi dan membandingkan alternatif ini untuk pekerjaan saat ini dan kemudian mengembangkan niat untuk berhenti atau tetap.

Niat untuk berhenti pada akhirnya mengarah pada perilaku turnover. Oleh karena itu, meskipun kepuasan kerja atau ketidakpuasan merupakan faktor penting untuk dipertimbangkan karena dapat memicu proses turnover secara keseluruhan dan karyawan mulai berpikir untuk berhenti, faktor lain ikut berperan untuk menentukan apakah karyawan akan benar-benar berhenti atau tidak. Hal ini juga berkaitan dengan persepsi terhadap beban kerja, dimana semakin tinggi persepsi terhadap beban kerja maka tentu saja akan semakin tinggi juga intensi untuk meninggalkan suatu perusahaan sebaliknya apabila semakin rendah maka tentu saja akan semakin rendah juga turnover intention dikarenakan karyawan tersebut pastinya sudah nyaman dan merasa cukup puas tidak merasa tertekan di dalam suatu perusahaan tersebut. Tetapi kembali lagi kepada kebutuhan daripada setiap karyawan yang berbeda-beda, tentu saja ada hal-hal lain atau faktor-faktor lain yang mempengaruhi turnover intention bukan hanya kenyamanan atau beban kerja yang ringan.

Tentunya setiap karyawan ingin memiliki kepuasan kerja yang tinggi menurut dirinya sehingga ia harus mencari pekerjaan yang lebih baik dan lebih baik lagi daripada sebelumnya. Dengan adanya harapan mendapatkan pekerjaan yang lebih baik daripada sebelumnya membuat niatan atau intensi untuk keluar meninggalkan perusahaannya yang sekarang. Tentunya hal ini akan ditambahkan apabila beban kerja yang didapatkan dalam perusahaan tersebut tinggi. Tentunya apabila persepsi terhadap beban kerja tinggi maka akan menghasilkan turnover intention yang tinggi juga pada suatu karyawan tersebut. Setiap karyawan pada satu perusahaan memiliki pandangan dan perasaan yang ber- 
beda-beda terhadap pekerjaannya. Pandangan dan perasaan tersebut dipengaruhi oleh beban kerja yang dirasakannya yaitu pekerjaan yang menuntut individu untuk memberikan energi atau perhatian (konsentrasi) yang lebih dan haris dikerjakan serta diselesaikan dalam waktu tertentu. Pandangan dan perasaan tersebut tentunya dapat bersifat positif maupun negatif. Pandangan, perasaan dari setiap karyawan tentunya akan berbeda dengan karyawan yang lain, sehingga dengan adanya perbedaan yang tidak menentu antar satu karyawan dengan karyawan yang lain memberikan rasa ketertarikan untuk meneliti variabel persepsi terhadap beban kerja ini.

Turnover terjadi di berbagai organisasi dikarenakan keinginan seseorang untuk mencari kenyamanan pada pekerjaannya. Di Amerika Serikat tercatat 3\% peningkatan turnover setiap bulan atau sekitar $36 \%$ per tahun (Robbins \& Judge, 2007), sedangkan di Indonesia perkiraan ini dihasilkan dari studi oleh Hay Group bekerjasama dengan Centre for Economics and Business Research seperti dilansir Top Career Magazine (2013). Studi tersebut memperkirakan jumlah karyawan yang akan berhenti pada tahun 2014 dapat mencapai 161,7 juta atau meningkat 12,9\% bila dibandingkan dengan tahun 2012 . Sedangkan di tahun 2015 turnover intention pada karyawan akan semakin meningkat hingga 13,4\%. Kawasan Asia Pasifik diperkirakan akan mengalami Ionjakan terbesar dalam tingkat pergantian karyawan tahun 2014. Tingkat turnover di Asia Pasifik akan mengalami kenaikan tertinggi di seluruh dunia, yakni naik $21,5-25,5 \%$ selama periode 2012-2018. Dikarenakan banyaknya karyawan yang melakukan turnover pada perusahaannya, persepsi terhadap beban kerja dianggap cocok untuk menjadi hubungan antara turnover intention tersebut.

Schultz dan Schultz (2006) menyatakan beban kerja sebagai terlalu banyaknya melakukan pekerjaan pada waktu yang tersedia atau melakukan pekerjaan yang terlalu sulit untuk karyawan. Persepsi terhadap beban kerja antara setiap individu atau karyawan pastinya berbeda-beda, oleh karena itu persepsi berperan dalam beban kerja sua- tu individu. Apabila terlalu banyaknya pekerjaan tentu akan meningkatkan perasaan atau persepsinya yang semakin buruk terhadap suatu pekerjaannya. Persepsi terhadap beban kerjanya menjadi negatif dan niat untuk meninggalkan perusahaannya menjadi lebih tinggi. Dalam penelitian yang dilakukan oleh peneliti saat ini, hal ini dapat disebabkan oleh pengaruh beban kerja yang berat dan mampu menyebabkan seseorang ingin memiliki niatan keluar dari pekerjaannya yang sekarang dan mencari pekerjaan yang lebih baik daripada sebelumnya.

Adapun rerata variabel turnover intention partisipan dalam penelitian ini tergolong tinggi. Menurut Allen dan Meyer (1971) bahwa usia mempengaruhi turnover intention seseorang. Karyawan muda mempunyai keinginan untuk melakukan turnover lebih tinggi daripada karyawan yang memiliki usia yang lebih tua. Hal ini disebabkan karena pekerja tua enggan berpindah-pindah tempat kerja karena berbagai alasan seperti tanggung jawab, tidak mau repot, ataupun rasa senioritas. Sedangkan karyawan dengan usia lebih muda masih ingin mencari jenjang karir yang lebih baik. Dibandingkan dengan pekerja yang lebin muda yang ingin mencari pekerjaan yang lebih baik dan lebih nyaman daripada sebelumnya, pekerja yang umurnya lebih tua lebih senang bekerja pada tempat yang sudah ada dan sudah menerimanya bekerja.

Turnover intention yang tinggi tentunya dimungkinkan oleh banyak penyebab, dalam penelitian ini dapat dikatakan bahwa penyebab yang memungkinkan adalah karena usia responden yang tergolong pada dewasa awal, di mana terdapat lebih banyak responden yang berusia antara 21 sampai 25 tahun dibandingkan dengan responden di usia lain. Karyawan yang berusia di kategori dewasa awal tentunya akan lebih mementingkan pekerjaan yang lebih baik dan lebih memiliki beban yang lebih rendah dengan penghasilan yang tinggi, sehingga karyawan pada dewasa awal tentunya akan mencari terus-menerus pekerjaan yang lebih cocok dan lebih memenuhi kebutuhannya sekarang dan di masa yang akan datang. Dengan adanya penghasilan dan kebutuhan yang ter- 
penuhi, pastinya karyawan akan mempertimbangkan untuk keluar dari suatu perusahaan tempatnya bekerja. Apabila dijelaskan lebih lanjut mengenai turnover intention karyawan dengan penghasilan yang lebih tinggi pastinya memiliki niatan untuk keluar dari perusahaan lebih rendah daripada yang memiliki penghasilan yang lebih rendah, tetapi dengan penghasilan itu sendiri tidak menutup kemungkinan bahwa karyawan dengan penghasilan yang tinggi akan tetap meninggalkan perusahaannya karena maksud lain. Maksud tersebut adalah karena beban kerja yang dikerjakan oleh karyawan pada suatu perusahaan tersebut.

Rerata variabel persepsi terhadap beban kerja partisipan tergolong sedang. Hal ini dapat dikatakan bahwa responden penelitian cukup netral terhadap pandangan beban kerja yang dirasakan oleh karyawan tersebut. Dengan pandangan terhadap beban kerja masing-masing karyawan tentunya akan berbeda-beda. Apabila dijelaskan dengan kategori lama bekerja untuk responden penelitian, cukup banyak responden penelitian yang dilakukan peneliti yang berada kurang dari 1 tahun. Hal ini dapat menyebabkan bahwa responden penelitian masih memiliki semangat yang tinggi dalam bekerjanya untuk mencari kenaikan pangkat dan mampu menjadi yang dominan dibandingkan dengan karyawan lain. Maka peneliti mampu mengaitkan dengan motivasi kerja yang dimiliki oleh responden penelitian, motivasi kerja juga akan memengaruhi persepsi terhadap beban kerja yang dimiliki oleh karyawan. Dengan adanya motivasi kerja yang tinggi tentunya persepsi terhadap beban kerja yang dimiliki oleh karyawan akan lebih rendah dibandingkan dengan karyawan yang memiliki motivasi kerja yang lebih rendah. Hal ini dikarenakan orang yang termotivasi dengan baik akan selalu melakukan pekerjaannya secara maksimal tanpa mementingkan beban kerja yang dimiliki oleh karyawan tersebut.

\section{Kesimpulan}

Berdasarkan hasil penelitian dan pembahasan yang telah dilakukan, dapat diketahui bahwa hipotesis yang diajukan diterima, yaitu terdapat hubungan yang signifikan antara persepsi terhadap beban kerja dengan turnover intention pada karyawan, dimana hubungan yang diperoleh adalah positif $(r=0,335)$. Berarti semakin tinggi persepsi terhadap beban kerja maka akan semakin tinggi juga kecenderungan turnover intention (niat untuk keluar dari perusahaan), sebaliknya apabila semakin rendah persepsi terhadap beban kerjanya maka akan semakin rendah pula kecenderungan untuk turnover intention (niat untuk keluar dari perusahaan).

Selain itu, nilai R Square $(r 2)=0,112$ menunjukkan bahwa persepsi terhadap beban kerja memberikan kontribusi sumbangan relatif sebesar $11,2 \%$ terhadap turnover intention dan sisanya $88,8 \%$ merupakan faktor lain di luar penelitian ini. Kemudian, hasil perhitungan rata-rata empirik turnover intention sebesar 84,80 yang berarti turnover intention pada karyawan di kawasan DKI Jakarta dikategorikan pada kategori tinggi. Hasil perhitungan rata-rata empirik persepsi terhadap beban kerja adalah 61,60 yang berarti persepsi terhadap beban kerja karyawan di kawasan DKI Jakarta dikategorikan sedang.

\section{Daftar Pustaka}

Aamodt, M. G. (2010). Industrial/ organizational psychology: An applied approach. (6th ed.). United States: Wadsworth Cengage Learning.

Abelson, M. A. (1987). Examination of avoidable and unavoidable turnover. Journal of Applied Psychology, 182386.

Allen, N. J. \& Meyer, J. P. (1997). Commitment in the workplace: Theory, research, and application. Thousand Oaks, CA: Sage Publication, Inc.

Arthur, J.B, (1994), "Pengaruh dari Sistem Sumber Daya Manusia terhadap Kinerja Produksi dan Perputaran". Academy of Management Journal, 37, 670-687.

Brough, P., \& Frame, R. (2004). Predicting police job satisfaction and turnover intentions: The role of social support 
and police organisational variables. New Zealand Journal of Psychology, 33 (1), 8-16. http://www.psychology. org.nz/wp-content/uploads/NZJPVol 331-2004-2-Brough.pdf

Du Plooy, J., \& Roodt, G. (2013). Biographical and demographical variables as moderators in the prediction of turnover intentions. SA Journal of Industrial Psychology, 39 (1), 1-12. http://dx.doi.org/10.4102/ sajip.v39i1.1070

Dewi, I. A. (2013). Hubungan antara persepsi terhadap beban kerja dengan komitmen organisasi karyawan divisi pelaksana produksi PT. Solo Kawistara Garmindo. Skripsi (Tidak dipublikasikan). Semarang: Fakultas Psikologi Universitas Diponegoro.

Gawron, V. J. (2008). Human performance, workload, and situational awareness measures handbook. (2nd ed.). USA: CRC Press Taylor \& Francis Group.

Juliandi, A. (2003). Kepuasan dan ketidakpuasan kerja dalam mempengaruhi intensi untuk bertahan atau keluar dari lingkungan pekerjaan. Jurnal IImiah "Manajemen dan Bisnis" Universitas Muhammadiyah Sumatra Utara, 3(1), 15-28. https://paul02583. files.wordpress.com/2007/11/3_1_2. pdf

Lathifah, L. (2008). Pengaruh konflik pekerjaan keluarga terhadap turnover intention dengan kepuasan kerja se bagai variabel intervening. Tesis (tidak dipublikasikan). Semarang: Fakultas
Ekonomi Universitas Diponegoro.

Lum, L., Kervin, J., Clark, K., Reid, F., \& Sirola, W. (1998). Explaining nursing turnover intent: job satisfaction, pay satisfaction, or organizational commitment. Journal of Organizational Behavior, 19 (3), 305320. doi: 10.1002/(SICl)10991379(199805)19:3<305::AID JOB843>3.0.CO;2-N

Mobley, W., Horner, O., \& Hollingsworth, A. (1978). An evaluation of precursors of hospital employee turnover. Journal of Applied Psychology, 63 (4), 408-414.

Pradana, A., \& Salehudin, I. (2015). Work overload and turnover intention of junior auditor in greater Jakarta, Indonesia. The South East Asian Journal of Management, 9 (2), 108124. http://journal.ui.ac.id/index.php/ tseajm/article/viewFile/4950/3446

Robbins, S. P., \& Judge, T. A. (2007). Organizational behaviour. (12th ed.). New Jersey: Pearson Education, Inc.

Schultz, D., \& Schultz, S. E. (2006). Psychology work today. (9thed.). New Jersey: Pearson Education, Inc.

Xiaoming, Y., Ma B. J., Chang, C. L., \& Shieh, C. J. (2014). Effects of workload on burnout and turnover intention of medical staff: A study. Etho Med, 8 (3): 229-237. http://krepublishers. com/02-Journals/S-EM/EM-08-0-00014-Web/S-EM-08-3-14-Abst-PDF/SEM-8-3-229-14-363-Shieh-ChichJen/S-EM-8-3-229-14-363-ShiehChich-Jen-Tx[4].pdf 